\title{
Implementation of Public Service Innovation in the IDOLA Program in Sleman
}

\author{
Agustina Rahmawati ${ }^{1}$ \\ \{agustinarahma@amikom.ac.id ${ }^{1}$, \\ AMIKOM Yogyakarta University, Indonesia ${ }^{1}$
}

\begin{abstract}
This article intends to provide an overview of the implementation of public service innovations in the Sleman District IDOLA program. Through a qualitative descriptive approach, this study discusses the implementation and factors that contribute to public service innovation on aspects of population and civil registration. The target of this study is the Dindukcapil Sleman and the Village as actors who deal directly with the community. The results showed that in the implementation of the IDOLA program there were still obstacles, namely network disruption, several villages that had not implemented the program, limited blanks and a lack of public understanding of the IDOLA program. The recommendation of this study is the need to build a culture to realize the importance of population documents and increase the consolidation between sectors to utilize integrated population data for development and government interests, population-oriented development, and NIK as Public Access (KIS, KIP, Farmer Cards, Fishermen's Cards, Cards Student / Student, Integrated PLN Card with NIK).
\end{abstract}

Keywords: Innovation, Public Service, IDOLA Program.

\section{Introduction}

Along with the increasing demands of the public for quick and easy access to public services, local government officials have made various innovations to answer this. Since the advent of the Administration of Indonesian Conscious Movement (GISA) program, every region in Indonesia is now supporting the program by developing various innovations in its implementation. Therefore, the innovation refers to the main GISA program, which is aware of ownership of population documents, aware of updating population data, aware of the use of population data, and consciously serving population administration towards a happy society. This raises the consequence that the Sleman Regency Government, through the Department of Population and Civil Registration, has made innovations to increase orderly awareness of population administration through the Population Service Document Integration Program (IDOLA). The IDOLA program is a form of simplification of population administration mechanisms and requirements in accordance with Regent Regulation No. 39 of 2017. Therefore, it is expected that the Sleman Regency Government can provide a more responsive population administration service to the community in Sleman Regency. This means that the Sleman regency government has the ability to innovate and the willingness to innovate which is an important element in the implementation of public services.

Nevertheless, this is a challenge whether the IDOLA program can be a solution to the problems of the Sleman Regency community over more responsive population administration. 
At present, there are still many residents in the Sleman Regency who have not recorded data. Furthermore, there were $98.46 \%$ of the 787,958 compulsory KTP in Sleman including data recording. This means that there are still 12,119 compulsories electronic KTPs that have not recorded data. That is, the consequence that arises is the problem of the elements and supporting factors of the integration of the entire process of updating population data through the provision of public services.

The research on the implementation of public service innovation programs has been carried out. In this case, the previous studies assessed that in every public service innovation program has limitations. First, Alawiyah [1] examines the implementation of the program to accelerate poverty reduction by the District Health Office of Samarinda, where the results of the study show that the new target group reaches $80 \%$ of the desired changes that have improved education and public health but have not been able to improve economic welfare and have not been able to reduce the number of poor people in Samarinda City. Second, Sulhan [2] examines the implementation of poverty reduction program policies through smart social and Indonesian guarantee cards for the community (case study in the kauman village in Malang), where the results of the study are community groupings conducted by officers related to facilitating the distribution of KPS and KIP especially the Kauman sub-district whose population reaches 560 residents, data shows that the poor have the right to receive as much as $30 \%$ of the KPS while the poor have the right to receive $5 \%$ KIP. Both studies show that the implementation of policies and programs is very dependent on the element of capacity and the value elements of the policies and programs offered.

\section{Research Method}

The researcher used descriptive research, precisely using qualitative descriptive research because the researcher intended to describe descriptively how the implementation of public service innovations in the IDOLA program in Sleman Regency.

Descriptive research is generally carried out with the main purpose, which is to systematically describe the facts and characteristics of objects or subjects that are precisely examined. In recent developments, descriptive research methods have also been carried out by many researchers because descriptive methods are very useful to get a variety of problems related to the field of education and human behavior [3].

\section{Results and Discussion}

In order to improve dynamic population administration services based on Sistem Informasi Administrasi Kependudukan (SIAK) leads to excellent service, efforts need to be made to integrate document and population services. This is done so that every important event and population incident that occurs can be recorded to update population data. Integration of population services is carried out with provisions that do not exceed the reporting deadline and there are no changes to other data elements. Integration of population document services is carried out on types of services, namely birth certificates, marriage certificates, divorce certificates, death certificates, child recognition deeds, child ratification certificates, and Child Identity Cards (KIA). Regents of Sleman Regency No. 39 of 2017 revoke Sleman Regent Regulation Number 80 In 2009. New and different things are the Child Identity Card Service 
(KIA), the utilization of population data and the granting of permits for access rights and access rights officers, as well as services for the issuance of birth certificates for children who do not have to enter the KK first.

\subsection{IDOLA Program Innovation}

Integration of Population Document Services (IDOLA) is an integrated service, namely if the community takes care of 1 (one) population document, they will get 3 (three) documents at once. In this case the people who make birth certificates for their children will automatically get birth certificates, changes / additions to family members on Family Cards (KK) and Child Identity Cards (KIA). This makes the community more efficient and easier to access services. This step is expected to increase the awareness of the Sleman community in orderly population administration. The image of an initially complicated and long-standing government bureaucracy has become increasingly adaptive in responding to people's needs.

\subsection{Factors that contribute to the implementation of public service innovations in the IDOLA program in Sleman Regency}

In carrying out the duties of population and civil registration services, Dindukcapil Sleman formulates service standards and various Standard Operating Procedures (SOPs) to control the strategic and operational functions of the program. For example, in the following display:

\subsubsection{Standard Operating Procedure in the Population and Civil Registration Service}

There is an integrated communication path that is carried out by Dindukcapil Sleman Regency with several stakeholders namely sub-districts, village governments, and RT / RW parties. This also makes the process of verification and matching of population data more effective and minimizes the occurrence of data duplication. Likewise, with the intensive socialization of the IDOLA program both through websites, print media, and the utilization of village apparatus, people are increasingly aware of the importance of recording population data.

\subsubsection{Incentives}

The supporting facilities and infrastructure in Dindukcapil Sleman Regency are in the form of ac waiting room facilities, CCTV cameras and electronic queue numbers that provide public comfort in accessing population services.

\subsubsection{Openness}

The resources of the Dindukcapil apparatus have received inputs from the DPRD so that the IDOLA program of the Sleman Dindukcapil can be sustainable. Dindukcapil is also very open in getting advice from the people of Sleman Regency, especially as program users through the suggestion boxes that have been provided either via the Dindukcapil Sleman website or directly in the service lobby.

3.2.4 Rejection is seen from the power of dynamics, interest groups, and policy monopolies in structures that can hinder change (innovation) 
a. Resistance occurs when there is a disruption of online system networks. Thus, the performance of the Dindukcapil apparatus in serving population and civil records data management. This can happen if Sistem Informasi Administrasi Kependudukan (SIAK) from the center is disrupted, and the system in the regions will automatically be disrupted.

b. There are still many villages that have not implemented Paman Timin and Lukadesi. Although since 2017 the IDOLA Program has been launched, in reality there are still villages that have not implemented Paman Timin and Lukadesi until May 2019. For example, based on a survey of researchers in Condong Catur village in Willayah, Sleman Regency will only begin to implement. This is according to information from the village officials there due to the high level of population density in the region, so that they only dared to start the program trial period in May 2019. As for other information, it was found that in the monitoring and evaluation of the implementation of IDOLA by Dindukcapil it also turned out that it was still not optimal. Monev is only conducted per semester through a coordination meeting alone without any written reports on the results of follow-up monitoring submitted back to the village.

c. Blank restrictions on population and civil registration. Even though the process of recording population data and information has been carried out through Sistem Informasi Administrasi Kependudukan (SIAK). Some d There is still a dependency on the availability of blank hardfiles from Dindukcapil Ministry of Home Affairs. This makes the administrative verification process sluggish.

d. Lack of public understanding of the IDOLA program. Since 2017 until May 2019, the level of public understanding of the IDOLA program is still not optimal. This is based on the statement from the village officials that there are still many people who are still confused and lay people who come to the Village Office and Dindukcapil by carrying out makeshift files that do not match the flow of requirements. Even though the conditions for accessing population products and civil registration have been posted on the bulletin board and can be accessed through the Dindukcapil, Subdistrict, and Village websites.

\section{Conclusion}

The innovation of IDOLA's public services in managing population data and civil registration in Sleman is a good effort of the local government to realize rapid service excellence for the community. However, this has not been supported by the government's capacity to implement the program both in terms of human resources, institutions and management so that the IDOLA program can run well. Therefore, it is necessary to build a culture of society to realize the importance of population documents, consolidate inter-sectors to utilize integrated population data for development and government interests, develop population-minded development, and NIK as Access to Public Services (KIS, KIP, Farmer Cards, Fishermen's Cards, Student / Student Card, Integrated PLN Card with NIK). 


\section{References}

[1] R. Alawiyah, "Implementasi Program Percepatan Penanggulangan Kemiskinan oleh Dinas Kesejahteraan Sosial Kota Samarinda,” 2016.

[2] M. Sulhan and T. Sasongko, "Implementasi Kebijakan Program Penanggulangan Kemiskinan melalui Kertu Penjamin Sosial dan Kartu Indonesia Pintar pada Masyarakat (Studi Kasus di Kelurahan Kauman Kota Malang),” JISIP J. Ilmu Sos. Dan Ilmu Polit., vol. 6, no. 1, 2017.

[3] M. S. Sukardi, "Penelitian kualitatif-naturalistik dalam pendidikan," Yogyakarta Usaha Kel., 2006. 